\title{
International Relations Theory and the Second Korean War
}

\author{
DAVID C. KANG \\ Dartmouth College
}

\begin{abstract}
Ever since the first Korean war in 1950, scholars and policymakers have been predicting a second one, started by an invasion from the North. Whether seen as arising from preventive, preemptive, desperation, or simple aggressive motivations, the predominant perspective in the west sees North Korea as likely to instigate conflict. Yet for fifty years North Korea has not come close to starting a war. Why were so many scholars so consistently wrong about North Korea's intentions? Social scientists can learn as much from events that did not happen as from those that did. The case of North Korea provides a window with which to examine these theories of conflict initiation, and reveals how the assumptions underlying these theories can become mis-specified. Either scholars misunderstood the initial conditions, or they misunderstood the theory, and I show that scholars have made mistakes in both areas. Social science moves forward from clear statement of a theory, its causal logic, and its predictions. However, just as important is the rigorous assessment of a theory, especially if the predictions fail to materialize. North Korea never had the material capabilities to be a serious contender to the U.S.-ROK alliance, and it quickly fell further behind. The real question has not been whether North Korea would preempt as South Korea caught up, but instead why North Korea might fight as it fell further and further behind. The explanation for a half-century of stability and peace on the Korean peninsula is actually quite simple: deterrence works.
\end{abstract}

\begin{abstract}
It is the very definition of a "rogue state." Poor, isolated, and bitter, North Korea is considered so dangerous that some U.S. officials want to build a $\$ 60$ billion missile-defense system to counter its threat.
\end{abstract}

- Justin Brown, Christian Science Monitor

War can only be prevented if you will fight and keep a strong stance. If a bully sees you preparing for a fight by running and working out, he will think differently. You must prepare for war in order to gain peace.

-Chun Doo-hwan, ex-ROK president

Science learns from surprise. Ever since the first Korean war in 1950 scholars and policymakers have been predicting a second one, started by an invasion from the North. The Defense Intelligence Agency (1997) has consistently considered a Korean war to be the primary near-term military concern of the United States, and with the revelations of a nuclear weapons program by North Korea in October

\footnotetext{
Author's note: For comments and advice, many thanks to Victor Cha, William Wohlforth, Stephen Brooks, and three anonymous referees. Special thanks to Mo Steinbrunner and Mike Spirtas of the Center for National Policy for their advice and support of this research.
} 
2002, the most recent worry is that North Korea may engage in a missile attack on the United States (The Economist, 1997; Ikle, 1998; Jordan, 1998; Eberstadt, 1999; Friedberg, 1999). A good example of this approach comes from Richard Betts (1994:66):

Since the direct attack in 1950, Pyongyang has frequently demonstrated its risk propensity in more consistently reckless provocations than any other government in the world.... Today pessimists worry about a North Korean nuclear weapons program. Would any government be more willing to do wild and crazy things with such weapons than the one that so regularly perpetrates acts like those mentioned above?

This is just the latest of a long series of dark predictions about an increasingly risk-acceptant North Korea. Earlier scenarios under which scholars have expected North Korea to invade include the 1961 military coup d'état in South Korea by Park Chung-hee that followed a year of turmoil in the South, the withdrawal of U.S. troops from South Korea under the Nixon doctrine of the early 1970s, the assassination of Park Chung-hee by his own security forces in 1979, the military coup d'état by Chun Doohwan in 1980, the mass demonstrations for democracy in 1986-87, and the nuclear crisis of 1992-94. ${ }^{1}$ Whether seen as arising from preventive, preemptive, desperation, or simple aggressive motivations, the predominant perspective in the west sees North Korea as likely to instigate conflict.

The theoretical underpinnings for these expectations come from theories of preventive war and power transitions (Cha, 1999a). Consider Norman Levin's (1990:42) assessment of North Korea: "the closing window of opportunity may cause an increasingly desperate North Korea to launch an attack before it's too late." This is hardly a new worry: fourteen years earlier, in 1978, Hakjoon Kim (1978:153) wrote that "the North is under increasing pressure to act soon. The Pyongyang regime might believe that if it fails to attack sooner or later, at least during the period when it enjoys the only real advantage over the South-its lead in military capability - it will inevitably lose in the long run." Yet for fifty years North Korea has not come close to starting a war.

This raises a question: why were so many scholars so consistently wrong about North Korea's intentions?

Social scientists can learn as much from events that did not happen as from those that did. The case of North Korea provides a window with which to examine these theories of conflict initiation, and reveals how the assumptions underlying these theories can become mis-specified. Either scholars misunderstood the initial conditions, or they misunderstood the theory, and I show that scholars have made mistakes in both areas. It is not surprising that the pessimists about North Korea have been wrong for the past thirty years because they misapplied power transition and preventive war theories to derive their pessimistic predictions. Upon closer examination, none of these theories was applicable to the Korean case. North Korea never had the material capabilities to be a serious contender to the U.S.ROK alliance, and it quickly fell further behind. So the real question has not been whether North Korea would preempt as South Korea caught up, but instead why

\footnotetext{
${ }^{1}$ During the nuclear crisis, Hajime Izumi (1992:8) wrote, "Given the past record, we cannot rule out the possibility of Pyongyang's taking some sudden, unanticipated action." Tong-Whan Park (1992:353) wrote, "One cannot rule out the possibility that Pyongyang may try to exploit a fluid international environment and unstable domestic situation, the result of which could well be a militarized dispute." See also Bailey (1994); P. Kim (1994); Spector and Smith (1991); and Perry (1990). On the threat during the 1980s see Polomka (1986); Kihl (1985); and Choi (1985). On North Korean moves following the 1979 assassination of Park Chung-hee see Wickham (1999:3032). On the "missed opportunity" for North Korean invasion in 1961 see Kiyosaki (1976:79); and personal correspondence from Robert Scalapino.
} 
North Korea might fight as it fell further and further behind. To paraphrase William Wohlforth (1994:99), "theorists tended to concentrate on dynamic challengers and moribund defenders. But in Korea the North was the moribund challenger, and the South was the rising defender."

Additionally, the Korean case highlights the difficulty realism has in dealing with actions short of war. Our theories of conflict are notoriously underspecified, and if war does not break out, realist theories have little to say about serious tensions that are potentially hostile and harmful. North Korea was far more hostile during the late 1960s than at present, but stopped well short of war. The past decade has also seen North Korea making unprecedented efforts to engage the west, most likely in hopes of improving its security in an altered geopolitical environment. Realist theories - with their emphasis on military force as the principal source of security and insecurity - provide little guidance for interpreting either of these strategies.

If North Korea was so weak, why did so many people apply preventive war and power transition hypotheses to the peninsula? Here the North Korean case illustrates some general problems with any non-post facto application of these theories. Since North Korea was not powerful, scholars hypothesized extreme preferences to North Korean leaders. These ancillary and ad hoc hypotheses about preferences have been smuggled into the theory to make it fit the Korean case: from psychological assumptions about an irrational North Korean leadership to assumptions of an extremely strong preference for expansion or invasion. Preventive war and power transition theories focus on the material conditions of relative power, but the real analytic lifting has been done by behavioral assumptions about intent. As I will show, none of these assumptions is tenable.

Additionally, pessimists rely on another ad hoc theory to predict war in Korea, one that is interwoven with preventive war and power transition theories but rarely elucidated as a distinct analytic argument. This approach-the "desperation" theory - argues that a country might rationally decide on war if the alternatives are even worse (Sagan, 1988; O'Hanlon, 1998; Cha, 2002). Countries falling to pieces have little to lose, so they may be tempted to launch a war even if the odds of success are very low, because the prospects for failure are certain with continued peace. However, this theory has never been systematically tested, and is based on speculative assumptions about how the North Korean leadership perceives the world. In fact, there are good reasons to think that, from a North Korean perspective, the alternatives may actually look the opposite of what scholars predict. With the examples of the Gulf War and the U.S. military action in Kosovo and their own crumbling military, North Korea may very well perceive certain destruction from an angry United States if they initiate war, but see numerous examples of regimes - such as Libya and Cuba - that have survived despite intense hardship and withering U.S. pressure. The flurry of North Korean diplomatic and economic initiatives in the past few years show that - far from having given up hope and seeing inevitable economic collapse - the North Korean leadership is actively pursuing a strategy they hope will ease their domestic problems. The desperation thesis relies upon a number of heroic assumptions, and any discussion of the thesis should explicitly analyze North Korea's leadership perceptions and attitudes, rather than asserting them.

These theoretical mistakes have led scholars to consistently overestimate the North Korean threat. If predictions are wrong, scholars should admit as much and attempt to understand why. Social science moves forward from clear statement of a theory, its causal logic, and its predictions. However, just as important is the rigorous assessment of a theory, especially if the predictions fail to materialize. Ad hoc fallback arguments that do not logically derive from the theory are spurious and they should be discarded as such. For example, arguments such as "leaders under stress make risky decisions and Kim Jong-il may still decide to preempt," should be dismissed as the speculation that it is. Exploring why scholars have 
misunderstood North Korea is both a fruitful and a necessary theoretical exercise. ${ }^{2}$ This is particularly important with the renewed crisis on the peninsula in autumn 2002. Although many observers view the North Korean weapons program as aggressive, social science theories explain such actions as deterrent in nature against a bellicose United States.

The explanation for a half-century of stability and peace on the Korean peninsula is actually quite simple: deterrence works. Since 1953 North Korea has faced both a determined South Korean military and, more importantly, U.S. military deployments that at their height comprised 100,000 troops as well as nuclear-tipped Lance missiles. Even today they include 38,000 troops, nuclear-capable airbases, and naval facilities that guarantee U.S. involvement in any conflict on the peninsula. While in 1950 there might have been reason for confidence in the North, the war was disastrous for the Communists, and without massive Chinese involvement North Korea would have ceased to exist. Far from exhibiting impulsive behavior after 1950, North Korea's leadership has shown extreme caution. Given the tension on the peninsula, small events have had the potential to spiral out of control, yet the occasional incidents on the peninsula have been managed with care on both sides. The peninsula has been stable for fifty years because deterrence has been clear and unambiguous.

North Korea is only one case, and we should be careful about drawing too many conclusions about preventive war and power transitions from just this example. However, North Korea is an important case, and examining how these theories have been applied to North Korea can be an illuminating theoretical exercise. In this paper I perform five tasks. First, I discuss briefly the theoretical literature on preventive war and power transitions, and I show that the antecedents necessary for application of the theory have not applied on the Korean peninsula. Second, I use the "madman hypothesis" to show how questionable ancillary assumptions can be smuggled into the preventive war and power transition theories, and I show why assuming irrationality is unproductive. Third, I examine the desperation theory and show that the alternative hypothesis, which predicts peace instead of aggression, is more convincing. Fourth, I supply an alternative explanation for fifty years of continual peace on the peninsula based on simple deterrence. Finally, I draw theoretical implications and conclude by showing how my analysis provides a different interpretation of the recent "nuclear revelations."

\section{Preventive War and Power Transition Theory Never Applied to Korea}

Power transition and preventive war theories are built upon two variables, relative power and satisfaction with the status quo (Most and Starr, 1989; DiCiccio and Levy, 2000). In addition, this literature makes generally realist assumptions such as nation-states are rational and the unit of analysis (Kugler and Lemke, 1996; Tammen et al., 1998), and the international system is generally anarchic (although susceptible to occasional and temporary order). The generic preventive situation consists of a stronger power, the "defender," and a weaker power, the "challenger," that is dissatisfied with the status quo. If the challenger's economic and military capabilities begin to match those of the defender, there exists the possibility that the defender will decide to fight a preventive war to keep the challenger from catching up, or that the challenger will fight after it catches up (Gilpin, 1981; Lebow, 1984; Hybel, 1986; Levy, 1987; Niou and Ordeshook, 1987; Houweling and Siccama, 1988; W. Kim and Morrow, 1992; Schweller, 1992). In empirical testing of the theories, Organski and Kugler defined power as equal when the challenger was at least 80 percent of the defender in size as measured by GNP, and tested whether

\footnotetext{
${ }^{2}$ There has been a small and growing group of scholars who argue that North Korea is not as dangerous as believed. See Harrison (2002); Roy (1994); Sigal (1997); and Kang (1995a, 1995b).
} 
preventive wars occurred as challengers approached or passed the 80-percent value (Organski and Kugler, 1980; Houweling and Siccama, 1988; Lemke and Werner, 1996; De Soysa, Oneal, and Park, 1997).

However, there are two generic problems in the way that scholars have applied the theories to the Korean peninsula. First, the theories predict peace if a small challenger falls further behind the defender (Lemke, 1997). If a nation was deterred from attacking when it was 60 percent the size of the defender, why would it attack after it had fallen to 30 percent, or even 20 or 10 percent, of the defender's size? Second, the analytic effort has been concentrated on the logic and measurement of the material aspects of the theory. Comparatively less theoretical work has attempted to make generalizable propositions about measuring satisfaction with the status quo, and yet this behavioral variable is considered just as important to the theory (W. Kim, 1991; Schweller, 1992; Lemke and Reed, 1996). The result, as we will see in section 2 , is a reliance on ancillary arguments.

Assessing the applicability of power transition and preventive war theories in Korea involves two calculations. The first calculation compares only North and South Korea, while the second calculation includes likely U.S. actions in these assessments. The typical approach has been to take both North and South Korea and compare them along a range of economic and military measures, and I will show that North Korea's capabilities were never preeminent over the South. Yet more important is an assessment of relative power that includes the U.S. forces that would be involved on the peninsula in event of a conflict. Scholars rarely consider this balance of forces, but this is a mistake, because any war would certainly involve the U.S. Both measures show clearly that the North was never preeminent over the South, and thus preventive war and power transition theories are not applicable to the Korean case.

South Korea has always had twice the population of the North. On the Korean peninsula, North Korea was never as large as the South, and even at its closest was no more than three-quarters the size of the South. Figure 1 shows estimates for GNP of North and South Korea from 1953 to 2000. It is clear that North Korea was never close to the South in absolute size, and indeed after 1960 rapidly began falling further and further behind. North Korea's GNP in 1960 was $\$ 1.52$ billion, while South Korea's GNP was $\$ 1.95$ billion. By 1970 North Korea had grown to $\$ 3.98$ billion, while in the South GNP was $\$ 7.99$ billion.

On a per capita income basis the North was never much further ahead of the South either. The North and South were roughly equivalent until the mid-1970s, when the South began to rapidly leave the North behind (Figure 2). In 1960 North Korea's per capita GNP was $\$ 137$, compared to $\$ 94$ in the South; and in 1970 the North's per capita income was $\$ 286$ compared to $\$ 248$ in the South. However, by 1980 the North's income was $\$ 758$ per capita, while the South's was $\$ 1,589$, and by $1990 \$ 1,065$ to $\$ 5,569$. Furthermore, in terms of preventive war, absolute size is what matters. Per capita income is not as important as absolute size because small nations may be rich on a per capita basis (Singapore, Switzerland) but be militarily insignificant.

In terms of defense spending, North Korea quickly fell behind the South, spending less on defense by the mid-1970s (Figure 3). As far back as 1977 the South was spending more than the North on defense in absolute dollar terms, $\$ 1.8$ billion in the South opposed to $\$ 1$ billion by the North. ${ }^{3}$ The only measure by which the North outspent the South was on a per capita GNP basis, which is an indicator of

\footnotetext{
${ }^{3}$ This has also been pointed out by Peter Hayes (1991:166), who estimates that if one includes U.S. Army expenditures both on ground forces and as part of the cost of the 7th Fleet, combined South Korean-U.S. military spending in Korea was about $\$ 12$ billion in 1986, four times what the North spent on defense that year.
} 


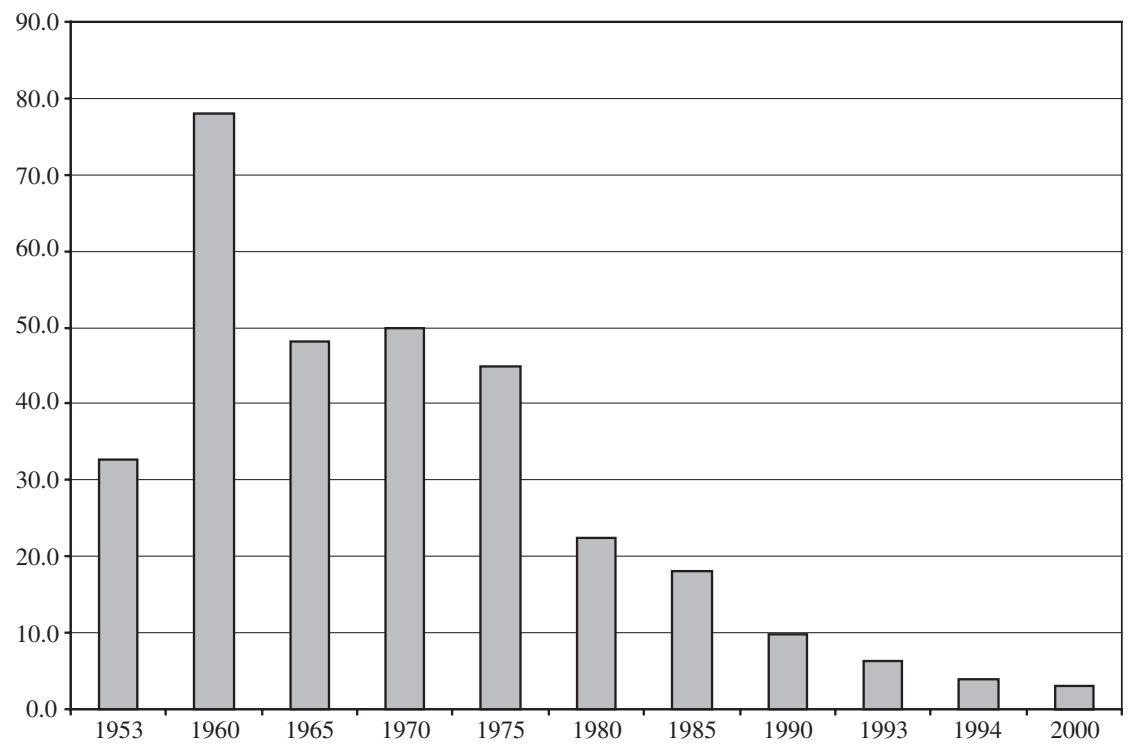

Source: Vantage Point 19(3) (July 1996):18; National Unification Board, The Economies of South and North Korea (Seoul: National Unification Board, 1988):30; and CIA World Factbook, various years (http://www.odci.gov/cia/publications/factbook/).

FIG. 1. North Korean GNP as a Percent of South Korea, 1953-2000

weakness, not strength (Hayes, 1991). Additionally, these numbers do not include military transfers from their respective patrons. Between 1965 and 1982 North Korea received $\$ 1.5$ billion in military transfers, mostly from the Soviet Union. Over the same time period South Korea received $\$ 5.1$ billion from the United States (ACDA, various years).

Thus the most common measures of power in international relations-economic size and defense spending - show quite clearly that North Korea was never larger than South Korea, has been smaller on both an absolute and a per capita basis than the South for at least thirty years, and continues to fall further behind. The onus is on power transition or preventive war theorists to explain the theoretical reasons that lead to the prediction that North Korea - having waited fifty years - would finally attack now that it is one-twentieth the size of the South.

In military capabilities North and South Korea were in rough parity for the first two decades following the war, and then the North began to fall behind. Figure 4 shows the number of men in the armed forces from 1963 to 1998. Most interesting is that North Korea did not begin its massive expansion of its armed forces until well into the 1970s. This is most probably a response to its falling further behind the South. But for the past thirty years, North Korea's training, equipment, and overall military quality has steadily deteriorated relative to the South.

The South Korean military is better equipped, better trained, and more versatile with better logistics and support than the North Korean military, and some assessments suggest that this may double combat effectiveness (Dupuy, 1990). Although the military has continued to hold pride of place in the North Korean economy, there have been increasing reports of reduced training due to the economic problems. Joong-Ang Ilbo, one of South Korea's major daily newspapers, quoted an unidentified Defense Ministry official as saying that North Korea's air force had made a hundred training sorties per day in 1996, down from three hundred to four hundred before the end of 1995, and that the training maneuvers 


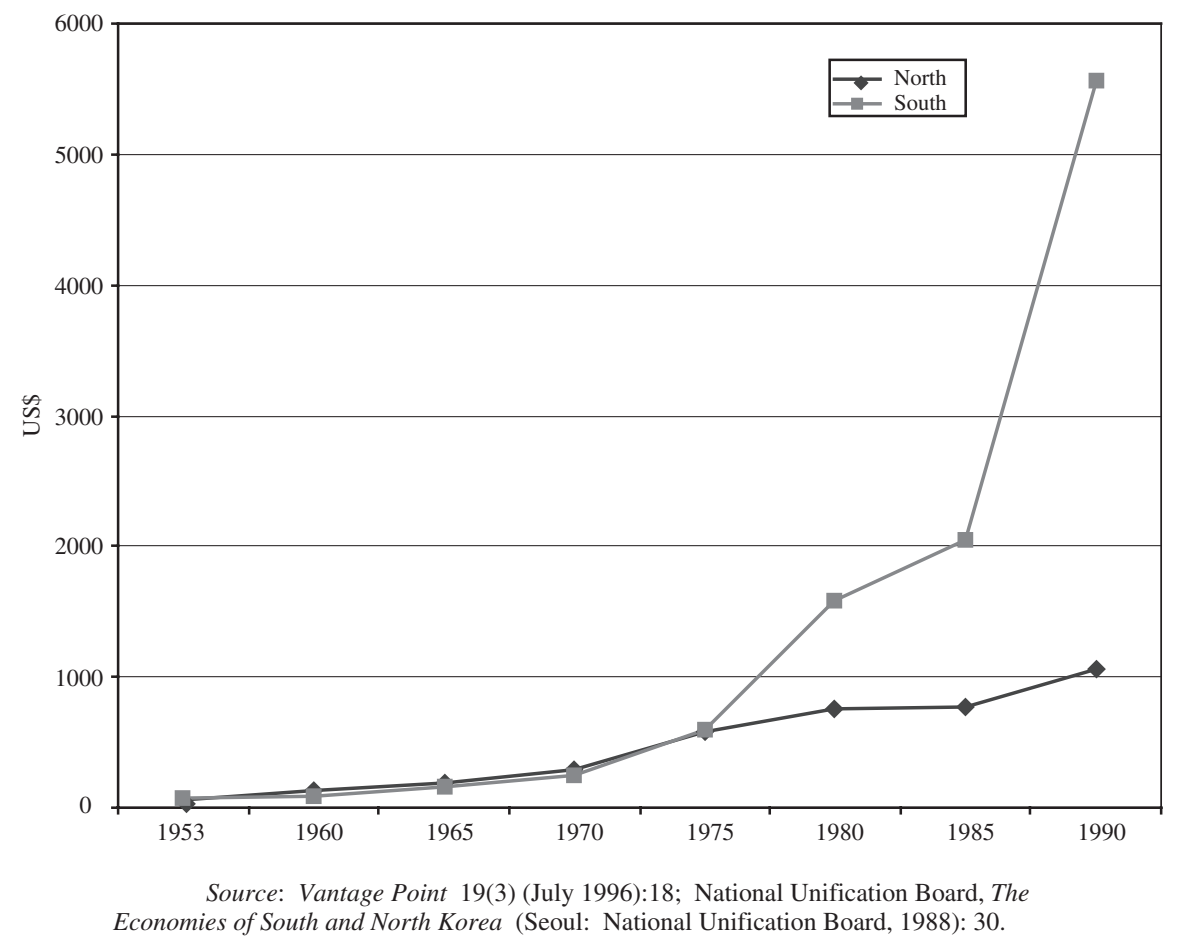

FIG. 2. Per Capita GNP of North and South Korea, 1953-1990

of ground troops had also been reduced to a "minimum level." American military officials have noted that individual North Korean pilots take one training flight per month, far less than the ten flights per month that U.S. pilots take. ${ }^{5}$ This drastically degrades combat readiness.

Table 1 shows a comparison of weaponry in North and South Korea in 1998. The bulk of North Korea's main battle tanks are of 1950s vintage, and most of its combat aircraft were introduced before 1956. Evaluations after the Gulf War concluded that western weaponry is at least two, or even four times better than older Sovietvintage systems (O'Hanlon, 1995:43). By the 1990s North Korea's military was large in absolute numbers but virtually worthless if measured by any indicator of quality. Michael O'Hanlon (1998:142) notes:

\begin{abstract}
Given the obsolescence of most North Korean equipment, however, actual capabilities of most forces would be notably less than raw numbers suggest. About half of North Korea's major weapons are of roughly 1960s design; the other half are even older.
\end{abstract}

To view the North as superior in military terms is mistaken, and South Korea could defeat the North by itself. But even more surprising about many of these accounts is that they measure the strength of the North Korean military only against that of the ROK, without including the U.S. forces, either present in Korea or as potential reinforcements. North Korea knows it would fight the United States as well as the South, and it is wishful thinking to hope that the North Korean military planners are so naïve as to ignore the U.S. military presence in South Korea, expecting the U.S. to pack up and go home if the North invaded.

\footnotetext{
${ }^{4}$ Associated Press, Sunday, January 14, 1996.

${ }^{5}$ Author's personal interview with a U.S. military official, June 11, 1994. See also Sullivan (1996).
} 


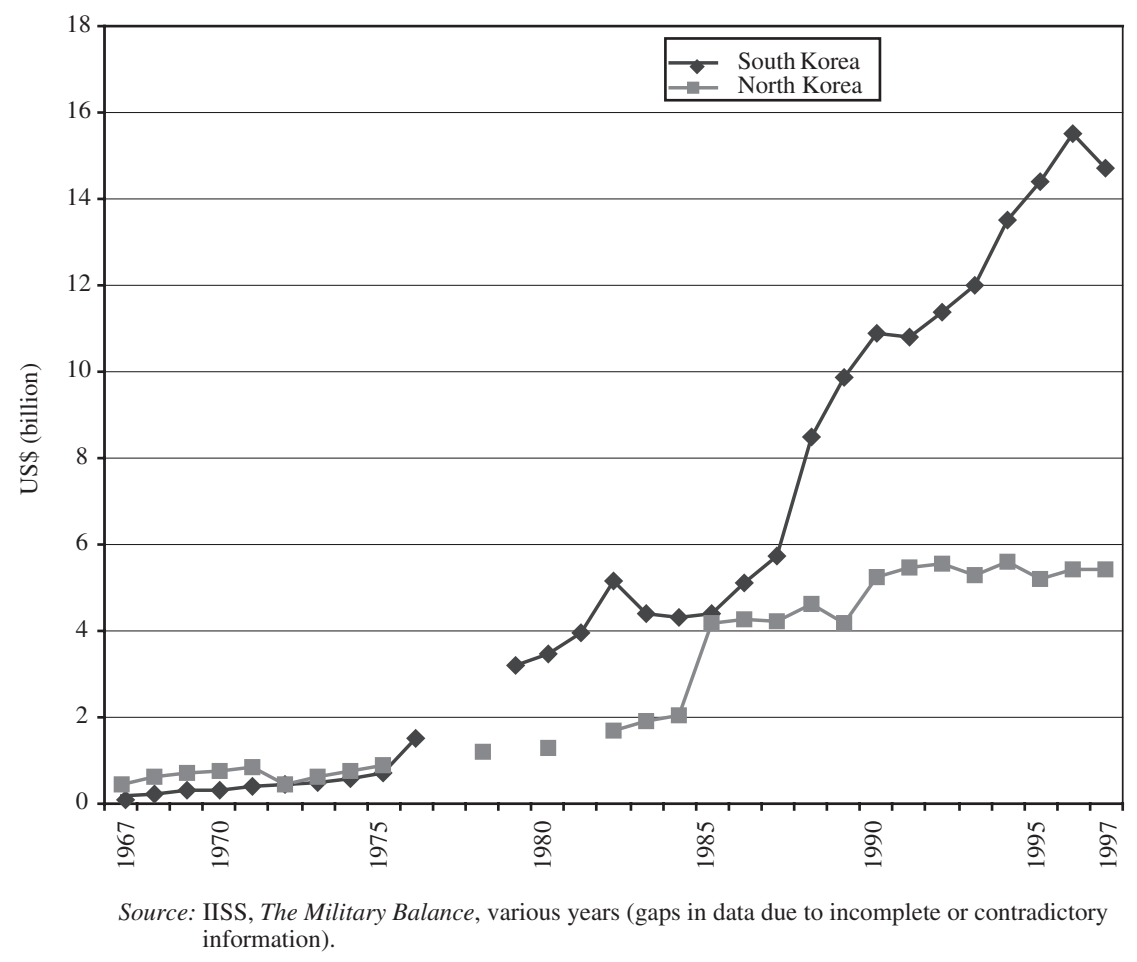

FIG. 3. Defense Spending, 1967-1997 (excludes military aid and transfers from third countries)

Comparisons between the South and the North that ignore the role of the U.S. are seriously misleading as to the real balance of power on the peninsula (Masaki, 1995; O’Hanlon, 1998).

In event of a full-scale conflict the United States has the potential to reinforce the peninsula with overwhelming power. Currently 36,000 U.S. troops are stationed in Korea, including the U.S. Second Infantry Division, and 90 combat aircraft including 72 F-16s. In addition, 36,000 troops are stationed in Japan, including the headquarters of the Seventh Fleet at Yokosuka naval base, 14,000 Marines, and 90 combat aircraft. This is only the beginning. More reinforcements would come mainly from the U.S. and be substantially larger in number (Oberdorfer, 1998).

This economic and military comparison of North and South Korea shows that North Korea never had a lead over the South, and after the 1960s quickly began falling behind. If there ever was a time North Korea might hope to invade it was the 1960s, when the United States was preoccupied with Vietnam and South Korea was only beginning its economic miracle, and when North Korea was closest to South Korea's capabilities. But even then North Korea was deterred by its inferior size and the stationing of two U.S. infantry divisions on the peninsula. Also, the larger geopolitical situation in Asia worked against any military action by the North, including a Sino-Soviet split that left neither of the Communist superpowers willing to risk a conflict on the Korean peninsula. Thus, instead of directly challenging the balance of power, during the 1960s Kim Il-Sung pursued a very unsuccessful Vietnamese-style subversion campaign against the South. ${ }^{6}$

Awareness of the role the U.S. plays on the peninsula was greater during the 1960s than it is today. Robert Scalapino (1963:46) noted that "[t]he leaders [of

\footnotetext{
${ }^{6}$ Precisely because terrorism is unlikely to start a major war, it is a recognition that deterrence works (Cha and Kang, 2003).
} 


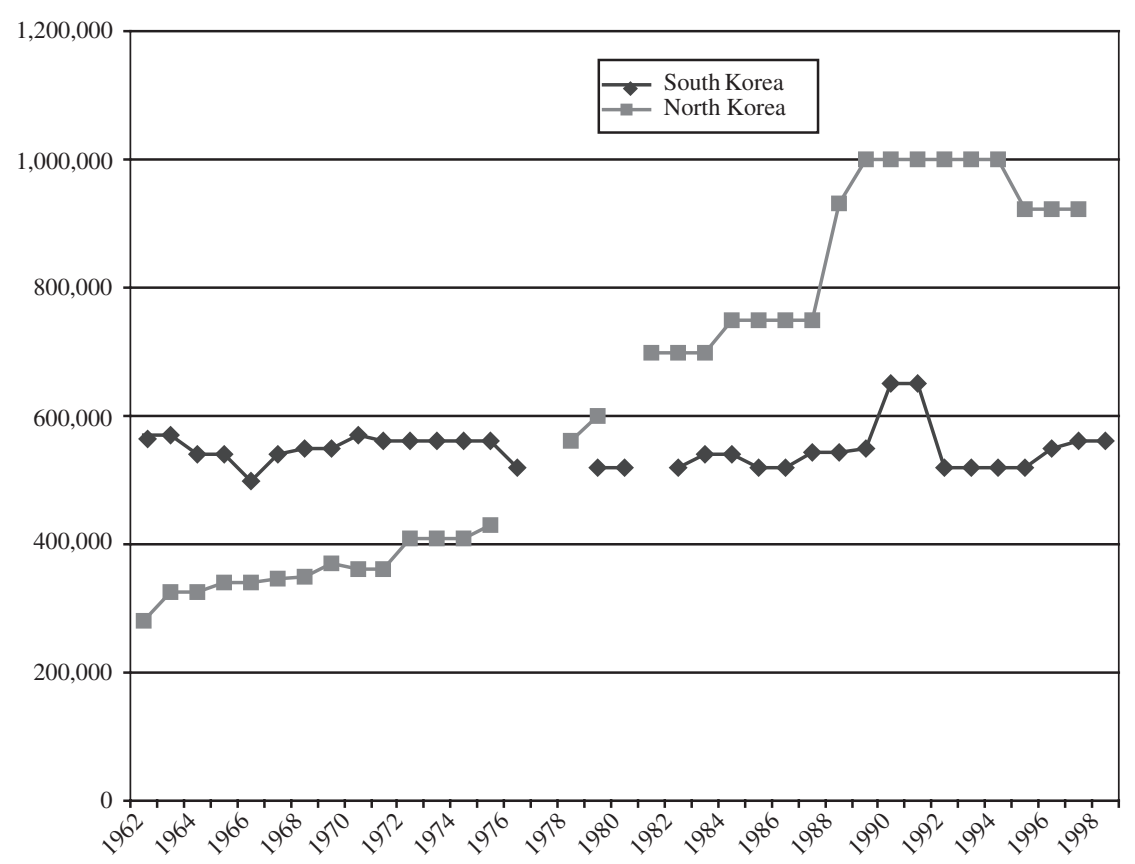

Source: IISS, The Military Balance, various years (gaps in data due to incomplete or contradictory information).

FIG. 4. North and South Korean Armed Forces, 1962-1998

TABLE 1. A Comparison of North and South Korea's Hardware in 1998

\begin{tabular}{|c|c|c|c|}
\hline Type of Hardware & North Korea & South Korea & Comments \\
\hline $\begin{array}{l}\text { Main battle } \\
\text { tanks }\end{array}$ & $\begin{array}{r}3,000: \text { T-34, T-54/55, } \\
\text { T-62, Type } 59\end{array}$ & $\begin{aligned} 2,130: & 400 \mathrm{M}-47 \\
& 850 \mathrm{M}-48 \\
& 800 \text { Type } 88\end{aligned}$ & $\begin{array}{l}\text { T-34 are WWII vintage; } \\
\text { T-55 introduced in } 1957 \\
\text { M-47 are WWII vintage; } \\
\mathrm{M}-48 \text { from } 1952\end{array}$ \\
\hline Fighter aircraft & $\begin{array}{l}107 \text { MiG-17 } \\
159 \text { MiG-19 } \\
130 \text { MiG-21 } \\
46 \mathrm{MiG}-23 \\
30 \mathrm{MiG}-29 \\
18 \mathrm{Su}-7 \\
35 \mathrm{Su}-25\end{array}$ & $\begin{array}{l}130 \mathrm{~F}-4 \mathrm{D} / \mathrm{E} \\
195 \mathrm{~F}-5 \\
60 \mathrm{~F}-16\end{array}$ & $\begin{array}{l}\text { US has } 72 \text { F-16 in } \\
\text { Korea and } 36 \text { in Japan; } \\
\text { U.S. also has } 54 \text { F-15 in Japan } \\
\text { MiG-17, -19, and -21 were all } \\
\text { introduced before } 1956 \text {; } \\
\text { MiG-29 in } 1983 \\
\text { F-4 introduced in } 1963 \text {; } \\
\text { F-5 in } 1972 \text {; } \\
\text { F-16 introduced in } 1980\end{array}$ \\
\hline Bombers & 82 Il-28 & - & \\
\hline
\end{tabular}

Source: The Military Balance 1997-1998 (London: International Institute for Strategic Studies, 1998); James F. Dunigan, How to Make War (New York: Quill, 1983).

China and North Korea] cannot think of successfully challenging the United States directly, in terms of economic or military competition.... Not able to challenge its primary foe militarily ... the DPRK government uses all of the techniques of enmity available to it." In fact, most scholarship in the 1960s focused only on the U.S.North Korean relationship, noting correctly that South Korea was clearly a minor player on the Korean peninsula at that time (Shinn, 1969:245; Kiyosaki, 1976:111). 
Indeed, North Korean actions during the 1960s reveal the difficulty realist theories have in dealing with actions short of war. If we define the dependent variable tightly - as major military action-North Korea did not engage in preventive action. But another possibility exists: harmful actions short of war. In the late 1960s, when North Korea was closest to the South in terms of capabilities, it was also the most aggressive. As its power waned in subsequent years, North Korea reduced its aggressive behavior. Thus, the preventive dynamic may have been operative in the peninsula, but North Korea was never powerful enough to undertake an invasion. And here it becomes important to distinguish between a theory and the theory's predictions. The theory predicts actions short of war, because the North was never powerful enough to consider war. What happened in the literature was that the pessimists ignored the theory and instead concluded the North was more threatening than it was in reality. Preventive war and power transition theories imply that moribund challengers will not attack. North Korea was never in a preeminent position relative to the South, and the real question for the pessimists is why do they continue to believe that a nation that is far behind and falling further behind might still attack.

\section{Why the Madman Hypothesis Makes No Sense}

If North Korea was so weak, why did so many scholars apply preventive war and power transition theories to the peninsula? The answer is that scholars smuggled a number of ancillary or ad hoc assumptions into the theory. Because the scholarly literature has paid such scant attention to understanding the theoretical underpinnings of dissatisfied or revisionist states, this leaves ample room for poorly defined assumptions to be inserted into the argument. Evaluations of national capabilities and alliances are comfortably third-image and realist in nature, whereas evaluations of "satisfaction" and leadership rapidly probe into domestic politics and even the psychology of individual leaders. Often this link is not directly stated, which both allows the scholar to make the case without clearly delineating the causal linkage and the evidence, and also plays on a generalized "assumption of guilt" that surrounds countries such as North Korea. When we don't know much about a country it is easy to assume the worst.

In the case of North Korea, these tended to be behavioral assumptions about the psychology of the North Korean leadership, and ranged from assuming that North Korean leaders had an intense preference for unifying the peninsula to assuming that Kim Il-Sung (and later, Kim Jong-il) was "impulsive and eccentric" (Thornhill and Ward, 2002). North Korea has been described as a nation of "paranoid survivalists" (Olsen, 1986:851) and "a renegade state" (Spector and Smith, 1991:8). Typical of this approach is a statement by John Perry (1990:188):

Rhetorical style and financial irresponsibility pale beside the impact on international public opinion of the inexplicable spasms of violence perpetuated by North Korea. Much can be said against the erratic ferocity of such behavior.

In 1992, James Pierce of the American embassy in Seoul said (1992) "Why would North Korea attack? Because Kim Il-Sung is not rational." The strong version of these psychological assumptions asserts that Kim Il-Sung and Kim Jong-il were truly irrational or paranoid. The weaker version of this argument emphasizes that leaders of authoritarian and secretive regimes may have different preferences or pressures from those of more widely understood countries. In both cases, however, if independent variables such as leadership truly matter, then scholars must incorporate them explicitly and consistently into their theories. In arguing that North Korea was unpredictable or irrational, scholars relied on these assumptions - often without evidence - to do the bulk of the analytic lifting. Yet even a 
cursory glance shows how untenable these assumptions are (Roy, 1994; Smith, 2000).

As in section 1, if we define the dependent variable tightly-as invasion - the madman approach is easy to dismiss. As an independent variable, the problem of defining an aggressive or expansionist state is not confined to the study of North Korea, and the question over aggressive intentions is actually a question of whether a country is likely to use force to achieve its goals: how badly does a country value the goal? What is their estimation of the costs and benefits? What is the likelihood of achieving that goal? (Huth and Russet, 1990:467-84; Lebow and Stein, 1990). The decision to pursue an "aggressive" or "expansionist" goal is thus composed of three separate calculations: the value of the prize, the costs that will be paid for that prize, and the probability of success. Thus while it may be that North Korea values quite highly the goal of unifying with the South on its own terms, in order to argue that North Korea actually poses a threat to the South one must show convincingly that North Korea positively evaluates all three conditions. Instead, this is often merely asserted, and a half-century of peace reveals that no matter how highly the Kims may have valued unification by force, they clearly have not evaluated the costs and probability of success positively enough to start a second war.

If the strong version of irrationality is fairly easy to dismiss, the weaker version is just as problematic. A looser dependent variable would incorporate actions short of war. However, even if we grant that the two Kims' attitudes were important, the question becomes how much of their value systems and attitudes explain North Korean behavior? This question rests on a counterfactual: if their attitudes and rationality have been important in explaining North Korean foreign policy, we should be able to believe that a different North Korean leader would have produced a different set of outcomes. What a focus on personality ignores, of course, is that we cannot infer actions from attributes if the situation also matters. As Waltz (1979:61) writes, "Just as peacemakers may fail to make peace, so troublemakers may fail to make trouble. From attributes one cannot predict outcomes if outcomes depend on the situations of the actors as well as on their attributes."

Discussions of irrationality do not get us very far. First, if a ruler truly is irrational or paranoid, it is impossible to make any causal link between that psychological state and expected outcomes. Second, such an approach is unfalsifiable and allows the scholar to post-dictively prove any argument that he makes. By resorting to an irrational demagogue as an explanatory variable, analysts appeal to a deus ex machina by which any North Korean action can be post-dictively explained, and by which any possible North Korean action can be possible.

Additionally, both Kim Il-Sung and Kim Jong-Il have been very capable leaders. All the evidence points to their ability to make sophisticated decisions and to manage palace, domestic, and international politics with extreme precision. Kim Jong-Il has kept power for seven years despite the widespread belief that he could not survive. There was speculation that a coup or instability could follow after his father's death in 1994, but that has not occurred (H. Ahn, 1994; Suh and Kim, 1994; Kim, 1995; Vantage Point, 1996). There has been no palace coup, no military coup, no extensive social unrest, no obvious chaos in the military, and no wholesale purge of various officials. Indeed, the transition from father to son was remarkably smooth. Kim Jong-il has remained in power through famine, flood, economic crisis, nuclear crisis, the loss of two major patrons in Russia and China, and U.S. pressure (Vantage Point, 1996; Oberdorfer, 1998). Military officials have become present at all levels of the government, but they have not vetoed the economic and diplomatic efforts made by the Pyongyang regime (S. Kim, 2000:152-54). Either Kim Jong-il is an extremely adroit leader, or the social and political fabric of North Korea is more resilient than we might think, or both. 
The record of Kim Il-Sung is similar. The elder Kim ruled for forty-nine years (1945-1994), maintaining power through tremendous change in North Korea and the world around it. North Korea actually has a record of skillful domestic management. As Nicholas Eberstadt (1995:132) wrote:

\begin{abstract}
Because North Korea presents such an unattractive - even freakish - face to the outside world, it has often been misjudged. In important respects the regime has been underestimated. Fanatical or surreal as this "red dynasty" may appear, many of its policies have been practical and effective. Of all Asia's communist states (including the USSR), only North Korea avoided famine in the course of its collectivization of agriculture.
\end{abstract}

The evidence used to argue that these leaders have been irrational or crazy is completely speculative, having to do with hair styles or propensities to like western movies. While it may be accurate to argue that western leaders do not like the preferences of the North Korean leadership, it is not possible to argue these were irrational leaders, unable to make means-ends calculations.

The relevant question remains whether foreign policy would have differed markedly. Given the circumstances that led to the division of the peninsula, the Cold War, the U.S. decision to confront Communism across Asia, and the SinoSoviet split of the late 1950s, it is hard to imagine a different outcome in which North Korea was not an authoritarian Communist regime, or that North and South would not be locked in competition. Even without Kim Il-Sung, or Kim Jong-il, North Korea would still have been locked in conflict with the South, a protégé of the Soviet Union, and faced a hostile U.S.

Finally, the evidence of North Korea's foreign policy is that it is cautious, not risky. In arguing that North Korea is unpredictably dangerous, scholars such as Richard Betts have emphasized sporadic terrorist activities that ended in 1987 - over fifteen years ago. There are three reasons why this is a misperception. First, and most important for the concern about a general war, none of the famous incidents (1968 Pueblo, Blue House attack, 1976 axe-murder) involved a general mobilization of the entire military. That is, North Korea has engaged in subversion and terrorism, but as noted earlier, this is far different from starting an all-out war. Second, Richard Betts - like most scholars - has selectively used the evidence. The reality is that the Korean peninsula is a highly tense place, and with so many troops close to each other on the DMZ, incidents are bound to happen. Less well known in the west is that a number of times U.S. forces have strayed into the northern side of the DMZ. In 1994, a U.S. helicopter strayed over the DMZ and was shot down, and in 1980 a U.S. OH-58 helicopter flew several kilometers north of the DMZ before realizing its error (Wickham, 1999:99). Finally, North Korea's hostile attempts at military subversion disappeared by the late 1980s as South Korea's domestic political situation became both more stable and more legitimate, and it was clear the South was not going to collapse from internal contradictions.

There is no causal argument in the literature that links terrorism with general military invasion, and none of the preventive war or power transition theories has any link between those variables and war. Instead, this evidence is smuggled into the theories to do the bulk of the analytic lifting, without explicitly being incorporated into the models. While the Kim dynasty is undoubtedly concerned with regime stability, it is hard to imagine any North Korean ruler that would act substantially different toward the South or the U.S. Any conceivable North Korean leader would be concerned with regime and state survival and deterring the South.

The world views of leaders may be important to understand, especially when assessing a secretive and cautious nation's conception of its security. However, if preventive war and power transition theorists believe that variables such as leadership truly matter, then they must incorporate them consistently and explicitly into their theories. This is problematic: theories of war initiation are generally 
third-image and realist, yet evaluations of satisfaction with the status quo and characterizations of risk-acceptance are second- or first-image. International relations scholars have not elucidated a theory of leadership that fits easily within the larger structure of preventive war or power transition theories, and the literature should be conscious of that fact. Ad hoc arguments are not convincing.

\section{The Desperation Theory Predicts North Korean Patience}

There is another argument in the literature that predicts a North Korean attack. In this view, a desperate nation may compare the certainty of collapse with the slim chance that they could win or at least improve their situation through a war, and choose to initiate a fight they have little probability of winning. In the case of North Korea, it is argued that their economy has contracted by at least 25 percent over the past decade, and famine and stagnation are overtaking the land. In this situation, the argument goes, North Korean leaders may see a certain collapse awaiting them if they do nothing. If so, North Korean leaders may rationally decide that a quick invasion of the South may be their only hope for survival. Desperation theorists argue that a "cornered tiger" can be increasingly dangerous and risk-acceptant in the hopes of some miraculous event changing the situation. ${ }^{7}$

The biggest problem with the desperation thesis is that it is based on scarce-and largely speculative - data about North Korea. Neither optimists nor pessimists have good data on North Korean attitudes, perceptions, or intentions. Thus we must be aware that we are inferring attitudes from little data, and be as self-conscious as possible about not imputing preferences through wishful thinking. Often the desperation thesis is merely asserted, without evidence that explains the psychological or perceptual bases of the North Korean leadership. Serious study must at a minimum be focused on what available evidence there is regarding the mindset of the North Korean leadership. ${ }^{8}$

Indeed, there is a compelling alternative hypothesis about the North Korean leadership's perceptions. North Korea, far from seeing its imminent demise and thus planning a desperate war against the South in hopes of survival, might well view its options in precisely the opposite manner from those who advocate the "desperation" thesis. That is, the North Korean regime might see a war against the U.S. as guaranteed suicide, but economic survival as a distinct possibility.

The North knows that a war against the South, or an attack on the U.S.-either through attacking the South or by lobbing a missile at the Aleutian islands-would be suicide. The differential in capabilities is so vast that there can be no other conclusion, and given the obvious enmity with which the United States views the North, to attack the United States is to ask for certain and swift annihilation. In the past decade the North has seen the U.S. have its way with Iraq, and more recently watched the U.S. bomb Kosovo from bases in the United States. In event of a conflict, the U.S. would have complete air and sea superiority almost instantly, and would be able to bomb North Korean positions at will. North Korea is quite aware of the U.S. hostility toward it, and is also aware that a war would likely be conclusive - there would be little opportunity for a negotiated settlement once the fighting began. ${ }^{9}$

\footnotetext{
${ }^{7}$ Victor Cha (1999) does a careful and thorough job in using concrete evidence in making his claims regarding North Korean perceptions. On war initiation by a weaker power see Paul (1994).

${ }^{8}$ The lack of evidence can cut both ways, and this section is aimed primarily at showing an equally compelling alternative interpretation that arises from the little data that we do have.

${ }^{9}$ There is another potential scenario for invasion - a quick "Seoul grab" (hopeful at best) followed by an attempt to negotiate a settlement on favorable terms. However, from a North Korean perspective, this scenario suffers the same problems as simple aggression or prevention, that once the fighting starts it will be very hard to contain. Additionally, if the North instigates a conflict, it is likely the U.S. and South Korea will not settle. This is the same problem the Japanese encountered in 1941 — the surprise attack solidified previously ambivalent U.S. sentiment in favor of total war.
} 
Additionally, North Korea has far better information about the actual quality and capabilities of its own military. As noted in the previous section, all indicators show that North Korea has large numbers and little else. Being aware of this, North Korea must know how badly outgunned, out-trained, and technologically outclassed they really are. From a North Korean perspective, starting a war with the U.S. may seem a sure losing bet, and North Korean planners quite reasonably might conclude that the certainty of annihilation comes from launching an attack against the U.S.

On the other hand, North Korea has numerous examples of countries whose leadership have survived for years despite withering and intense U.S. pressure. Libya and Cuba are examples of countries that the United States has spent years attempting to eliminate. Yet these nations continue to survive. Indeed, in these countries the economic situation is much worse and U.S. pressure is far more acute than it is in North Korea.

What evidence do we have that North Korean leaders do not see imminent collapse of their regime? On the military front, North Korea has not attacked in fifty years, so their revealed probability assessment is that they view war as a losing proposition. On the economic front, most evidence points to a North Korean leadership that-far from having lost all hope and going into a bunker mentality - has been actively pursuing a number of options through which it can survive into the future. The flurry of diplomatic initiatives in the past few years is prima facie evidence that North Korean leaders have not given up hope for survival. If the leadership had truly had no hope, they would not even bother to try such initiatives.

Indeed, there is compelling evidence that the North plans on surviving indefinitely (Noland, 1997). Most significantly, despite the nuclear revelations of the fall of 2002, North Korea has made considerable progress in economic reforms and in repairing relations with the international community. Given the dire situation in which North Korea finds itself, one key question is whether the North Koreans are serious about their indicated desire to open normal relations with the rest of the world. In theoretical terms, realism has a hard time dealing with a northern strategy that can be viewed as seeking an end to enmity with the U.S., South Korea, and Japan in order to improve its security. In practical terms this means examining first and foremost whether North Korea genuinely wishes to repair relations with these countries. The evidence points to an affirmative answer. Such a strategy would also account for the North's repeated and clear desire to trade its nuclear and missile programs in return for security guarantees. ${ }^{10}$ Even in November 2002, DPRK ambassador to the U.N. Han Song Ryol said "our government will resolve all U.S. security concerns through the talks if your government has a will to end its hostile policy" (Sigal, 2002). In addition, the economic sector has changed dramatically. The proper comparison is not how closely North Korea has come to effecting a genuine capitalist transformation (very little), but rather how far they have come from the command economy of 1989 (very far).

There is growing evidence that North Korea is serious about opening to the west, and that it desires normal political and economic relations with the rest of the world. This fact should not be ignored with a focus purely on the weapons program in the North. Politically, North Korea has changed a number of its laws and the constitution itself in order to provide a legal framework for foreign investment. Although there has been foreign investment in North Korea since the 1970s, a major push for opening has only occurred in the past decade. In 1999 the Joint Production and the Joint Venture laws were amended to allow for projects outside the Rajin-Sonbong area. Until that time pure foreign investment enterprises were

${ }^{10}$ The North has repeatedly offered to negotiate about its missile and nuclear programs (Wagner, 2001). 
allowed to invest only in the Rajin-Sonbong area. ${ }^{11}$ The government continues to create the legal foundations that allow international investment. For example, there were eleven constitutional amendments in 1998 alone.

North Korea has also been attempting to join a number of international institutions. To date, North Korea attempted unsuccessfully to join the Asian Development Bank in 1997, and has recently indicated that it may apply to join the IMF (H. Kim, 2000). In addition, North Korea has also been actively courting middle powers around the region. Australia and Italy have recently normalized ties with the North, and Canada formally recognized North Korea. ANU has trained two groups of North Korean officials from the Ministry of Foreign Affairs in a yearlong economics course. ${ }^{12}$ In July 2000, the Philippines became the last ASEAN country to normalize relations with North Korea.

In economic relations, the North is increasingly open to a foreign presence on its soil. South Korea has led the way, with South Korean conglomerates rapidly expanding their activities in the North with the blessing of both South and North Korean governments. Hyundai continues to be the most ambitious South Korean company, most recently announcing plans to restore an inter-Korean railroad and create a trade zone near Haeju on the west coast of Korea that could produce $\$ 20$ billion of exports. The Haeju project will add to its existing Kumgang tours and other construction projects already under way. ${ }^{13}$ Samsung is currently negotiating with the North Korean government in an attempt to place its logo in Pyongyang, and has recently begun exporting consumer electronics from its electronic industrial complex of over 1.65 million square meters in factories in the North. ${ }^{14}$ LG has been manufacturing televisions in North Korea since 1996. There are over 700 South Koreans currently living and working in North Korea, and Nampo port houses 180 South Korean companies.

The Rajin-Sonbong free trade zone continues to show slow and halting progress. This zone has a mixed history: by the end of 1999 total foreign investment is estimated at \$125 million, of which almost half came from the Emperor Group of Hong Kong for its construction of a hotel and casino (Economist Intelligence Unit, 2000:49). However, with help from the UNDP, in late 1998 North Korea opened its own business school in the SEZ, the Rajin Business Institute (RBI) along with a Business Information Center (BIC).

North and South Korea are working to reopen the rail line between the two countries and have actually cleared landmines in a section of the De-Militarized Zone in preparation. South Korean companies increased their investments and trade with the North, and companies from other nations have begun to look at the North with greater interest. ${ }^{15}$ In June 2000, for example, over eighty U.S. companies attended a briefing by the Commerce Department regarding the recent lifting of U.S. sanctions on North Korea. The companies included IBM, Hewlett Packard, Oracle, Caterpillar, Dupont, and Phillip Morris. In addition, in July 2000 the foreign ministers of North and South Korea met before the ASEAN Regional Forum (ARF) meetings and pledged to extend cooperation in a number of areas, including reunification of divided families, economic cooperation, and the joining of international organizations. Japan and North Korea have reopened discussions regarding potential normalization of relations.

\footnotetext{
${ }^{11}$ For the full text of the current and past DPRK Constitutions, see the Japanese-run People's Korea site, (http://www.korea-np.co.jp/pk/).

${ }^{12}$ Personal communication with Professor Ronald Duncan, Executive Director, National Centre for Development Studies, Asia Pacific School of Economics and Management, Australian National University.

${ }^{13}$ Jungang Ilbo, April 16, 2000 (http://www.joins.com/top.html).

14 "Samsung Group Chairman Wants to Visit North Korea," Asia Pulse, May 3, 2000.

15 "Telecom Cos. Moving Briskly to Begin Business in North Korea," Korea Times, July 26, 2000.
} 
Most importantly, North Korea has been making overtures to the west for the past decade. Table 2 shows the series of diplomatic initiatives undertaken by the North since 1989. Note that these initiatives began at the end of the Cold War, when North Korea's international situation changed most drastically, and that these initiatives began before the nuclear crisis. Substantial progress was made until 1992 and the nuclear crisis, but with the Agreed Framework of 1994 these initiatives began again. This record shows that North Korea has been actively pursuing some type of rapprochement with the United States and the west for some time, and that it was the United States that was preoccupied with the potential nuclear and missile capabilities of the North. Table 2 is not intended to be a comprehensive chronology of all the mini-crises and issues surrounding U.S.-North Korea relations over the past decade. The table is focused only on showing North Korean diplomatic moves aimed at opening relations with the west. This "tit-for-tat" sequence of moves fell apart in the increasingly tense atmosphere following the terrorist attacks of September 11, 2001.

This is important for two reasons. First, North Korea has been the instigator of rapprochement: U.S. engagement has followed, rather than led, North Korea's initiatives (Sigal, 2002). Second, this is evidence that North Korea never fell into the bunker mentality that the desperation theorists rely upon to make their argument.

Finally, and perhaps as significant as these large changes in North Korean foreign policy, there are the "quiet changes" that have taken place. International agreements and government negotiations tell one story, but the changing actions of the average North Korean is just as important a story. In 1995 English replaced Russian as the required foreign language in high school (Quinones, 2000). At the Northeast Asian Economic Forum in 1999 that included Russia, China, Mongolia, Japan, and the two Koreas, all representatives spoke in their own language, except the North Koreans who spoke English (Babson, 2000). Interpreters get daily articles from the Wall Street Journal and other western newspapers. UN personnel have now visited almost every county in the North, and Chinese investors have begun to locate in the North. The World Food Program has foreigners living in every North Korean province, a previously unthinkable situation. CNN and BBC are available in Pyongyang. On a recent visit to Pyongyang, Ken Quinones, director of the Mercy Foundation, was asked by North Koreans to bring videos of The Titanic and The Little Mermaid.

Some of these changes are very small. And the overall progress has come nowhere near to being an "open society." But the relevant point is the comparison to how different North Korea is today than where it was even five years ago. The changes are obvious and consequential. Most importantly, these changes could not have occurred without the explicit consent of the top leadership. Even the North Korean military has been reported to be supportive of these recent moves. South Korean newspaper Jungang Ilbo reported that Jo Myong-rok, the first deputy chairman of the DPRK National Defense Commission, said on June 15 that the Commission appreciates with satisfaction the construction of the unification begun with ROK president Kim Dae-jung's visit to Pyongyang. Jo said at the farewell luncheon hosted by DPRK leader Kim Jong-il, "Let's practice the joint declaration with all our heart and with loyalty." 16 Jo also traveled to Washington and met with President Clinton in autumn 2000, and for his official visit he wore his military garb. This was widely interpreted as a symbolic show that the military was supportive of the opening by the North.

These changes do not mean that North Korea will abandon its command economy any time soon. North Korea's opening is cautious and tentative, not wholesale. And a North Korean opening up will not be the kind of wholesale rhetorical and ideological change that the U.S. expects and wants. But the key point

\footnotetext{
${ }^{16}$ See Jungang Ilbo, June 15, 2000 (http://www.joins.com/top.html).
} 
TABle 2. The Sequence of Diplomatic Moves, 1988-2000

\begin{tabular}{ll}
\hline & South Korea, U.S., and Japan \\
\hline July 7, 1988 & Roh's Six Point initiative \\
September 1988 & Seoul Olympics, USSR attends \\
October 1988 & US eases restrictions on contact with \\
& NK ("5-point policy")
\end{tabular}

November 1988

May 24, 1990

May 31, 1990

May 31, 1990

September 24, 1990

September 27, 1991

December 13, 1991

December 31, 1991

January 6, 1992 January 7, 1992

January 12, 1992

January 30, 1992

1993-94

July 1994

October 1994

September 1995

January 1995

September 1995

September 1996

April 1996

1996

Kanemaru visits NK, proposes normalization of Japan and North Korea

Bush announces removal of nuclear weapons from South Korea

US and ROK cancel Team Spirit

US agrees to political meeting with

NK in New York City

As part of the Agreed Framework, US partially lifts economic sanctions, allowing DPRK use of US banking system

Protocols agreed upon for mail delivery, telephone systems, and other accommodations for South Korean, United States, and Japanese nationals to live and work in North Korea
North Korea

North Korea asks for bilateral meetings in Beijing

Kim Il-Sung relaxes policy on US troops in South Korea, stating they can stay for the time being

North Korea proposes re-starting North-South dialogue

NK returns first of US MIA remains from the Korean War

South Korea and North Korea enter the UN

Agreement on Reconciliation, NonAggression, Exchanges, and Cooperation with ROK

Joint Declaration on

Denuclearization of the Korean peninsula

NK delays refueling reactor

NK announces it will sign the IAEA safeguards agreement "in the near future"

Nuclear crisis

NK signs IAEA safeguards agreement

Jimmy Carter travels to North Korea Kim Il-Sung agrees to measures to stop the nuclear crisis

Agreed Framework

Due to famine, North Korea allows World Food Program unprecedented access to North Korea
Along with UNDP and UNIDO, North Korea hosts investment and business forum for Rajin-Sonbong Daewoo begins joint-venture in Nampo Joint US-North Korean MIA searches 
TABLE 2. Continued

\begin{tabular}{|c|c|c|}
\hline & South Korea, U.S., and Japan & North Korea \\
\hline December 1996 & $\begin{array}{l}\text { US approves license to Cargill } \\
\text { Corporation for trade with North } \\
\text { Korea }\end{array}$ & \\
\hline June 1997 & & $\begin{array}{l}\text { North Korea applies to join the Asian } \\
\text { Development Bank }\end{array}$ \\
\hline August 1997 & \multicolumn{2}{|c|}{ KEDO groundbreaking } \\
\hline September 1997 & $\begin{array}{l}\text { First visit of IMF to } \\
\text { North Korea }\end{array}$ & \\
\hline 1997 & \multicolumn{2}{|c|}{$\begin{array}{l}\text { Discussions over and US lobbying on behalf of North } \\
\text { Korean admission to the Asian Development Bank }\end{array}$} \\
\hline November 1998 & & $\begin{array}{l}\text { Rajin Business Institute opens in } \\
\text { North Korea }\end{array}$ \\
\hline 1998 & & $\begin{array}{l}11 \text { constitutional amendments to } \\
\text { provide legal framework for foreign } \\
\text { investment and trade in North Korea }\end{array}$ \\
\hline 1999 & & $\begin{array}{l}\text { EU discussions at the UN General } \\
\text { Assembly in New York }\end{array}$ \\
\hline 1999 & & $\begin{array}{l}\text { Hyundai begins Mt. Kumgang tours } \\
\text { in North Korea }\end{array}$ \\
\hline 1999 & & $\begin{array}{l}\text { Joint Production and Joint Venture } \\
\text { laws allow projects outside the Rajin- } \\
\text { Sonbong special economic zone }\end{array}$ \\
\hline June 2000 & \multirow{2}{*}{\multicolumn{2}{|c|}{$\begin{array}{l}\text { Kim Dae-jung and Kim Jong-il summit in Pyongyang } \\
\text { Meeting of divided families in Seoul }\end{array}$}} \\
\hline August 2000 & & \\
\hline October 2000 & Madeleine Albright visits Pyongyang & Gen. Jo visits Washington, D.C. \\
\hline
\end{tabular}

Note: Table modeled after Sigal (1998).

is that this behavior is not consistent with the hypothesis that the Northern leadership see the imminent demise of its regime. Quite the opposite - this is a leadership that has been vigorous and active on a number of diplomatic fronts for over a decade. ${ }^{17}$

North Korean actions over the past five years do not lead to the conclusion that their leadership is desperate and increasingly paranoid. Rather, the North Korean leadership is active and interested in engaging the world. Economic stagnation, while clearly a cause for concern in North Korea, may not automatically result in a deleterious effect on the political prospects for the current regime. If the regime is coherent enough, and if the regime is willing to use repression and ideological indoctrination, revolt from below is unlikely to occur. More significant, the evidence shows that North Korea is interested in some opening and reform, however halting. Thus, although in theory the desperation thesis may be interesting in the abstract, the evidence points to the fact that the North Korean leadership knows that a war would be suicide, and also that it realizes some reform and opening may allow it to survive into the future.

\section{Simple Deterrence: Why North Korea Did Not Attack: 1953-2002}

North Korea has not attacked for fifty years because deterrence has been solid. Despite the tension that has existed on the peninsula, the balance of power has

\footnotetext{
${ }^{17}$ One key question that is beyond the scope of this paper is whether such reform can actually happen without triggering an internal collapse of the regime by unleashing reformist forces that it cannot control. For discussion on this point, see Ahn (1994).
} 
held. For over fifty years neither side has attempted to mount a major military operation, nor has either side attempted to challenge the balance of power. North and South Korea have been caught in a zero-sum, winner-take-all, mutual hostage situation. Both sides have wanted the other to lose; both sides can destroy the other. ${ }^{18}$ Any war on the peninsula would have disastrous consequences for both sides. The North, although it has a numerically larger armed forces, faces a much more highly trained and capable U.S.-ROK armed forces. This led to stalemate: there was little room for barter or bargaining. An almost total absence of linguistic, ethnic, and religious cleavages leaves no simple way to "divide the pie," and the relatively constricted geographic situation intensified an already acute security dilemma between the two sides. The result has not been surprising: although tension is high, the balance of power has been stable. Far from being a tinderbox, both sides have moved cautiously and have avoided major military mobilizations that could spiral out of control.

Why did deterrence not fail in Korea? The U.S. deterrent made a North Korean attack useless. Analysts in this respect have generally missed the forest for the trees, for although analysts often refer to the "U.S. tripwire" and deterrent posture, they continue to ignore the deterrent and focus instead on force-levels, terrorism, or subversion by the North (H. Kim, 1990; Tow, 1991).

Yet how can the Korean peninsula be stable when continual streams of scholars, diplomats, and politicians call the Korean peninsula a tinderbox? The reasons adduced by scholars as to why they worry about North Korea's intentions are attributes, and little mention is made of the situation within which North Korea must make decisions. Analysts argue that North Korea started the Korean war in 1950, and that North Korea has perpetrated a number of terrorist attacks, and therefore they are aggressive. The important point is that full-scale war is not now an option for the North, nor has it been since 1950. The U.S. deployment in South Korea makes deterrence robust and the chances of war on the Korean peninsula are remote. North Korea, for all its bluster regarding the South, has never directly challenged the central balance of power.

Although tension is high on the peninsula, North Korea's military-both conventional and missile systems - exist to deter the South and the U.S. from becoming too adventurous. Decades of animosity and mistrust on both sides makes negotiation and communication difficult. Implicit in U.S. policy of the 1990s has been an expectation that North Korea will engage in unilateral disarmament. This implicit U.S. policy has demanded that the North abandon its military programs, and only afterwards would the U.S. decide whether or not to be benevolent (Huntley and Savage, 1999).

From a realist perspective, it is not hard to see why the North has had problems with this. Although North Korea's missile program is part of their deterrence strategy, the main source of deterrence against the South is the artillery that holds Seoul hostage. And although North Korea wants to join the community of nations, they do not intend to relinquish their sovereignty or self-determination. As one North Korean diplomat (Nautilus Institute, 1999) noted: “The Agreed Framework made American generals confident that the DPRK had become defenseless; the only way to correct this misperception is to develop a credible deterrent against the United States." In addition, North Korea has indicated a willingness to negotiate away its missile program in return for improvements in its security with the United States.

North Korea could blow up terrorist bombs in downtown Seoul or Tokyo (or Washington, D.C.) every week if they wanted to. But the North Koreans have not done that, because their goal is survival, not suicide and random destruction (Cha,

\footnotetext{
${ }^{18}$ One estimate (Baek, 1998) calculates that a war on the Korean peninsula would cost the U.S. more than $\$ 60$ billion and result in 3 million casualties, including 52,000 U.S. military casualties.
} 
1999; Suro, 2000). As for rogue states and their alleged plans to fire a couple of nuclear warheads at the United States, there are three basic reasons to doubt this threat. First, North Korea has not yet developed this capability - it is only feared that eventually they may do so. Second, it would be suicide, since any attack on the U.S. would result in massive American retaliation, and North Korea's efforts over the past decade show that it has an intense desire to survive. Finally, why develop an expensive ballistic missile to shoot at the United States when it would be so much easier just to smuggle a nuclear weapon into the United States? It is important to distinguish between capabilities and intentions - North Korea already has the capability to blow up bombs in these cities, but their intentions are aimed at survival, not increasing tension. And while missiles will not give North Korea any more terrorist capability than is already possible through smuggled bombs, missiles do provide a military deterrent (Kang, 1995a).

Even paranoiacs have enemies. The U.S. is hostile to Pyongyang, and it is not accurate to pretend that the U.S. only wants to be friends and that North Koreans are merely paranoid. This is not to argue whether either side holds the moral high ground, nor to argue that the North Koreans are innocent lambs; clearly America has reason to mistrust the North. But North Korea also mistrusts the U.S. - they know very well that the ultimate U.S. goal is the transformation or even the obliteration of their way of life - and North Korea has reason to be wary. The difficulty comes in how one country slowly begins to trust another country.

There has been no war on the Korean peninsula for fifty years because deterrence has held. And as the North grows ever weaker relative to the South, the chances for war become even slimmer.

\section{Conclusion: Theoretical Implications and the Nuclear Revelation of 2002}

When outright North Korean invasion began to appear unlikely, scholars fell back on preventive war, and then preemptive war, the madman hypothesis, and then the desperation hypothesis as reasons to view the North as the aggressor. Yet for fifty years the reality on the Korean peninsula has falsified these predictions one by one. Deterrence on the peninsula has been strong enough to swamp any other potential causes of war on the peninsula, and continues to be so today. This study has shown that scholars need to be self-conscious in their application of assumptions and causal logic. If a well-specified theory such as preventive war or power transition does not appear to be borne out by the empirical record, scholars should acknowledge this and attempt to understand why. Although North Korea is merely one case, it is an important case and one that has figured prominently in the scholarly literature.

Preventive war and power transition theories actually predict that North Korea will not undertake adventurous actions. However, scholars have consistently misapplied these theories to the Korean peninsula. Scholars should pay closer attention to the antecedent conditions of the theories, and also be more selfconscious about the behavioral variables that implicitly carry the bulk of the argument. The literature has focused on measuring power, and less energy has been spent on measuring satisfaction with the status quo. If perceptions and intentions matter, then the theory should explicitly state how these behavioral variables relate to the timing, sequence, and intensity of the preventive motivation. Scholars should not let these variables sneak in and do the heavy lifting.

Other ad hoc arguments that are also thrown into the mix should be identified and discarded. The most common example of this "ad hoc-ism" is the "you never know" critique. This critique argues that there is a non-zero probability that North Korea may attack, and that therefore we should take steps to counter that possibility. This critique is theoretically and methodologically unfounded. Whether couched in terms of "accidents happen" or "mistakes get made" or "you never know, leaders under stress do irrational things," this argument is no more than an 
assertion that uncertainty exists in the world. Without a causal argument that links North Korean leaders to an unprovoked attack, using uncertainty as the prime cause of such an attack is vacuous. We have no logical reason to think that North Korean leaders are any different than any other leaders in the world, nor do we have any logical reason to think that deterrence which has held for fifty years might suddenly dissolve like dew in the summer sun. The preventive war and power transition theories are similarly susceptible to "you never know-ism." If in 1992 (or 1978 , or 1961) scholars argued strongly that a window of opportunity was closing for North Korea, and yet by 2001 there has still been no invasion, it is spurious to argue "you never know," and that North Korea may still launch a preventive war in 2003.

If North Korea is seeking accommodation with the rest of the world, why did they re-start their nuclear weapons program? In a climate where the U.S. calls North Korea a terrorist nation and top U.S. officials such as Rumsfeld discuss war on the peninsula, it is no surprise that the North feels threatened. If North Korea really wanted to develop nuclear weapons, it would have done so long ago. Rather, it restarted its program as a deterrent to U.S. "preemptive action" against it.

The 1994 Agreed Framework was a process by which both sides set out to slowly build a sense of trust. And both sides began hedging their bets very early in that process. Since both the United States and North Korea did not fulfill many of the steps even during the Clinton administration, the Agreed Framework was essentially dead long before last fall's nuclear revelations. The accepted wisdom in the United States is that North Korea abrogated the Agreed Framework by restarting its nuclear weapons program. However, even the Clinton administration was never eager to implement its side of the bargain, and both U.S. administrations have violated both the letter and the spirit of the agreement. For example, the first lightwater replacement reactor was scheduled to come online in 2003, and it was clear as early as 1998 that this replacement reactor would be at least three years behind schedule, due to U.S. reservations and hesitance. Furthermore, the Bush administration made clear from the beginning that it had serious doubts about the Agreed Framework: the inclusion in the "axis of evil" speech made it clear that the Bush administration did not trust the North. For the Framework to have any hope of being even modestly successful, both sides needed to implement the steps much more enthusiastically.

The collapse of the AF is disappointing because North Korea is actively seeking accommodation with the international community. In addition to a voluntary moratorium on testing its missiles which has lasted from 1999 to the present, North Korean economic reforms undertaken in the past decade are both dramatic and substantial, and these reforms are as much a part of North Korea as is the nuclear program. Overlooked in the last six months are a number of consequential changes that are beginning to transform North Korea. In July 2002 a market system was introduced for the entire country, including allowing prices to determine supply and demand. Last September the North announced the creation of a special economic zone in Shinuiju. Even during the last six months, work has begun to clear off a section of the DMZ in order for work to reconnect the railroad between North and South Korea. And perhaps most tellingly, this September Kim Jong-il finally admitted that the North had kidnapped Japanese citizens in the 1970s, after three decades of denials.

Economic reforms can be slow to manifest themselves. But the economic changes under way in North Korea are consequential, and they are becoming irreversible. It makes no sense to criticize the North for being isolationist and then refuse to trade with them. The North needs economic assistance-but far from being blackmail, the assistance North Korea needs will help open up its economy and ultimately its political system.

If my analysis is correct, the current crisis has a clear solution. If North Korea wants security from the U.S. first and foremost, then a policy of isolation will be 
ineffectual. Isolation is better than pressure, because pressure will only make North Korea even more insecure. But even isolation is at best a holding measure. Economic sanctions and economic engagement are also unlikely to be successful in getting the North to abandon its weapons program. These are secondary goals to a regime that wants better ties with the U.S. To dismiss North Korea's security fears is to miss the root cause of North Korea's actions.

\section{References}

Ahn, B. (1994) The Man Who Would Be Kim. Foreign Affairs 73:94-108.

Babson, B. (2000) Remarks at the conference, "The North Korean System at the Dawn of the $21^{\text {st }}$ Century." University of California, April 7.

BAEK, G. (1998) "Bringing an End to Brinksmanship." Washington Times Nov 15, B4.

Bailey, K. C. (1994) North Korea: Enough Carrots, Time for the Stick. Comparative Strategy 13: 277-282.

BetTs, R. K. (1994) Wealth, Power, and Instability: East Asia and the United States after the Cold War. International Security 18:34-77.

ChA, V. (1999) The Rationale for Enhanced Engagement of North Korea: After the Perry Policy Review. Asian Survey 39:853.

ChA, V. (2002) Hawk Engagement and Preventive Defense on the Korean Peninsula. International Security 27:40-79.

Cha, V., And D. C. Kang (2003) Nuclear North Korea: A Debate on Engagement Strategies. New York: Columbia University Press.

Choi, Y. (1985) The North Korean Buildup and Its Impact on North Korean Military Strategy in the 1980s. Asian Survey 25:341-355.

De Soysa, I., J. Oneal, and Y. -H. Park (1997) Testing Power-Transition Theory Using Alternative Measures of National Capabilities. Journal of Conflict Resolution 41:509-528.

DiCiccio, J., And J. Levy (2000) "Power Shifts and Problem Shifts: The Evolution of the Power Transition Research Program." Manuscript. Rutgers University.

Dupuy, T. N. (1990) Attrition: Forecasting Battle Casualties and Equipment Losses in Modern War. Fairfax, VA: HERO Books.

Eberstadt, N. (1995) Korea Approaches Unification. London: M. E. Sharpe.

Eberstadt, N. (1999) The Most Dangerous Country. National Interest 57:45-54.

Economist Intelligence Unit (2000) Country Report: North Korea. London: Economist Intelligence Unit.

Friedberg, A. (1999) “Loose Cannon.” New York Times Review of Books, Dec. 12, 23.

GiLPIn, R. (1981) War and Change in World Politics. Cambridge: Cambridge University Press.

Harrison, S. (2002) Beyond the Axis of Evil: What Price for a Nuclear-Free Korea? Remarks delivered at the Carnegie Endowment for International Peace, May 10.

Hayes, P. (1991) Pacific Powderkeg. Lexington, MA: Lexington Books.

Houweling, H., And J. Siccama (1988) Power Transitions as a Cause of War. Journal of Conflict Resolution 32:87-102.

Huntley, W., AND T. SAVAge (1999) “The Agreed Framework at the Crossroads" Nautilus Research Institute, Policy Forum Online \#99-05A, March 11.

Huth, P., AND B. Russet (1990) Testing Deterrence Theory: Rigor Makes a Difference. World Politics 42:466-501.

Hybel, A. R. (1986) The Logic of Surprise in International Conflict. Lexington, MA: Lexington Books.

IkLE, F. (1998) U.S. Folly May Start Another Korean War. Wall Street Journal, Oct. 12, A18.

Izumi, H. (1992) North Korea and the Changes in Eastern Europe. Korean Studies 16:1-12.

Jordan, A. (1998) Coping with North Korea. Washington Quarterly 21:33-46.

KANG, D. C. (1995a) Preventive War and North Korea. Security Studies 4:330-363.

KANG, D. C. (1995b) Rethinking North Korea. Asian Survey 35:253-267.

Kinl, Y. W. (1985) Korea's North-South Dialogue Rests on a Powder Keg. Far Eastern Economic Review (Oct. 17):64.

Kim, H. (1978) Unification Policies of South and North Korea: A Comparative Study. Seoul: Seoul National University Press.

Kim, H. (1990) U.S.-South Korean Security Relations: A Challenging Partnership. Korean Journal of Defense Analysis 2:149-160.

Kiм, H. (1995) North Korea after Kim Il-Sung and the Future of North-South Korean Relations. Security Dialogue 26:21-42. 
KIM, P. S. (1994) Will North Korea Blink? Matters of Grave Danger. Asian Survey 34:258-572.

KIM, S. S. (2000) North Korea in 1999. Asian Survey 40:151-163.

KIm, W. (1991) Alliance Transitions and Great Power War. American Journal of Political Science 34: 833-850.

Kim, W., And J. Morrow (1992) When Do Power Shifts Lead to War? American Journal of Political Science 36:896-922.

Kiyosaki, W. (1976) North Korea's Foreign Relations: The Politics of Accommodation, 1945-75. New York: Praeger.

Kugler, J. And D. Lemke, eds. (1996) Parity and War: Evaluations and Extensions of the War Ledger. Ann Arbor: University of Michigan Press.

Lebow, R. N. (1984) Windows of Opportunity: Do States Jump Through Them? International Security 9:147-186.

Lebow, R. N., And J. Stein (1990) Deterrence: The Elusive Dependent Variable. World Politics 42: 336-369.

Lemke, D., ANd W. Reed (1996) Regime Types and Status Quo Evaluations: Power Transition Theory and the Democratic Peace. International Interactions 22:143-164.

Lemke, D., And S. Werner (1996) Power Parity, Commitment to Change, and War. International Studies Quarterly 40:235-260.

Levin, N. (1990) Global Detente and North Korea's Strategic Relations. Korean Journal of Defense Analysis 2:33-54.

Levy, J. S. (1987) Declining Power and the Preventive Motivation for War. World Politics 40:82-107.

MaSAKI, S. (1995) The Korean Question: Assessing the Military Balance. Security Studies 4:365-425.

Most, B., AND H. Starr (1989) Inquiry, Logic, and International Politics. Ann Arbor: University of Michigan Press.

Nautilus Institute (1999) DPRK Report no. 19 (July-August).

Niou, E. M. S., And P. C. Ordeshook (1987) Preventive War and the Balance of Power: A GameTheoretic Approach. Journal of Conflict Resolution 31:387-419.

Noland, M. (1997) Why North Korea Will Muddle Through. Foreign Affairs 76:105-118.

Oberdorfer, D. (1998) The Two Koreas: A Contemporary History. New York: Addison-Wesley.

O'Hanlon, M. (1995) Defense Planning for the Late 1990s: Beyond the Desert Storm Framework. Washington, DC: Brookings Institution.

O'Hanlon, M. (1998) Stopping a North Korean Invasion: Why Defending South Korea Is Easier Than the Pentagon Thinks It Is. International Security 22:135-170.

Olsen, E. A. (1986) The Arms Race on the Korean Peninsula. Asian Survey 26:851-867.

Organski, A. E. K., And J. Kugler (1980) The War Ledger. Chicago: University of Chicago Press.

PARK, T. -W. (1992) Issues of Arms Control Between the Two Koreas. Asian Survey 32:353.

Paul, T. (1994) Asymmetric Conflicts: War Initiation by Weaker Powers. Cambridge: Cambridge University Press.

Perry, J. C. (1990) Dateline North Korea: A Communist Holdout. Foreign Policy 80:172-191.

Pierce, J. (1992) Remarks at the Second U.S.-Korea Forum. Seminar at the Institute for Far Eastern Studies, Kyungnam University, Seoul, Korea, October 15.

Polomka, P. (1986) The Two Koreas: Catalyst for Conflict in East Asia? Adelphi Papers 208. London: International Institute for Strategic Studies.

Quinones, K. (2000) Remarks at the conference, The North Korean System at the Dawn of the $21^{\text {st }}$ Century. University of California, April 7.

Roy, D. (1994) North Korea and the Madman Theory. Security Dialogue 25:307-316.

SAGAN, S. (1988) The Origins of the Pacific War. Journal of Interdisciplinary History 18:893-922.

ScalaPInO, R. (1963) “The Foreign Policy of North Korea.” In North Korea Today, edited by Robert Scalapino. New York: Praeger.

Schweller, R. L. (1992) Domestic Structure and Preventive War: Are Democracies More Pacific? World Politics 44:235-269.

Shinn, R. -S. (1969) Area Handbook for North Korea. Washington, DC: Government Printing Office.

Sigal, L. (1997) The North Korean Nuclear Crisis: Understanding the Failure of the "Crime and Punishment" Strategy. Arms Control Today 27:3-13.

SigAL, L. (1998) Disarming Strangers. Princeton, NJ: Princeton University Press.

SigaL, L. (2002) “North Korea Is No Iraq: Pyongyang's Negotiating Strategy" http://nautilus.org/fora/ security/0227A Siga.html

Smith, H. (2000) Bad, Mad, Sad or Rational Actor?. Why the "Securitization" Paradigm Makes for Poor Policy Analysis of North Korea. International Affairs 76:111-132. 
Spector, L. S., And J. R. Smith (1991) North Korea: The Next Nuclear Nightmare? Arms Control Today 21:8-13.

Suh, J., And B. Kim (1994) "Prospects for Change in the Kim Jong-il Regime.” Series no. 2 Policy Studies Report. Seoul: Research Institute for National Unification.

Sullivan, K. (1996) “U.S. Troops Train to Fight N. Korea.” Washington Post, June 7, A30.

Suro, R. (2000) “Ex-Defense Officials Decry Missile Plan.” Washington Post, May 17, A2.

Tammen, R., et al. (1998) The Imbalance of Power: Strategic Policies for a Hierarchic World, Manuscript.

The Economist (1997) "Sound the Alarm: Subtitle: Defector Says North Korea Is Preparing for War." April 26, 34.

Thornhill, J., And A. Ward (2002) The Puzzle of How to Deal with North Korea's Strange Autocrat. Financial Times, Dec. 15, 7.

Tow, W. (1991) Reassessing Deterrence on the Korean Peninsula. Korean Journal of Defense Analysis 3:179-218.

VANTAGE POINT (1996) 19:6-8.

Wagner, A. (2001) D.P.R.K. Extends Missile Pledge as U.S. Readies to Resume Talks. Arms Control Today (June: http://www.armscontrol.org/act/2001_06/korjun01.asp).

Waltz, K. (1979) Theory of International Politics. Reading, MA: Addison-Wesley.

Wickham, J. A. (1999) Korea on the Brink: From the 12/12 Incident to the Kwangju Uprising, 1979-1980. Washington, DC: National Defense University Press.

Wohlforth, W. (1994) Realism and the End of the Cold War. International Security 19:91-129. 